\title{
Isolation, Identification, and Critical Points of Risk of Escherichia coli 0157:H7 Contamination at Aceh Cattle Breeding Centre
}

\author{
Teuku R. Ferasyi ${ }^{1,6, *}$, Mahdi Abrar ${ }^{1,6}$, Muhammad Subianto ${ }^{2}$, Cut Afrianandra ${ }^{3}$, Muhammad Hambal $^{1,6}$, Razali Razali ${ }^{1,6}$, \\ Ismail Ismail ${ }^{1,6}$, Nurliana Nurliana ${ }^{1,6}$, Rastina Rastina ${ }^{1,6}$, Wahyu E. Sari ${ }^{1,6}$, Safika Safika ${ }^{4}$, Vierman Vierman $^{5}$, Nellita $_{\text {Mutia }}{ }^{5}$, \\ Rina A. Barus ${ }^{5}$, Yusmadi Yusmadi ${ }^{5}$, Teuku S. Rosa ${ }^{6}$, and Rezky Ramadhan ${ }^{6}$ \\ ${ }^{1}$ Faculty of Veterinary Medicine, Universitas Syiah Kuala, 23111 Banda Aceh, Indonesia \\ ${ }^{2}$ Faculty of Mathematics and Natural Sciences of Syiah Kuala University, Banda Aceh, Indonesia. \\ ${ }^{3}$ Faculty of Economics and Bussiness of Syiah Kuala University, Banda Aceh, Indonesia. \\ ${ }^{4}$ Faculty of Veterinary Medicine of IPB University, Bogor, Indonesia. \\ ${ }^{5}$ Livestock Breeding and Fodder Centre (BPTU-HPT), Indrapuri, Aceh Besar. \\ ${ }^{6}$ Centre for Tropical Veterinary Studies of Syiah Kuala University, Banda Aceh
}

\begin{abstract}
This study was aimed to identify possible critical points of Escherichia coli (E. coli ) O157:H7, a pathogenic agent, contamination in aceh cattle breeding centre. For this purpose, samples were collected from cattle faeces, hand of workers (animal keepers), and water sources in the farm using cross-sectional approach. A number of 85 samples of cattle faecal swab were collected randomly from the animals in the breeding centre. The samples of swab of hand of all workers (15 persons) were collected before and after work. Then, the water sources from 11 cattle house locations in the breeding centre were collected. The water sources were divided into three different locations, namely the water containers, taps, and water puddle on the floors. At each source a number of 11 samples were collected. Isolation of E. coli was conducted on Eosin Methylene Blue Agar (EMBA), followed by identification on Sorbitol MacConkey Agar (SMAC). Then Molecular subtyping of E. coli O157:H7 genes was conducted using multiplex-PCR analysis. Data were analysed descriptively. The results of this study showed that 72 samples (85\%) among 85 samples were positive for $E$. coli and the rest of samples were positive for other types of bacteria. Sample isolation from swabs of hand was found 3 positive $E$. coli before work and 1 positive $E$. coli after work from 15 workers. The most potential water sources for $E$. coli contamination were the water in taps, and water puddle on the floor of cattle houses. Then, two of samples of $E$. coli isolated from rectal swab were confirmed as $E$. coli O157:H7 using PCR test, based on the presence of stx2 gene. In conclusion, the risk of presence of E. coli as zoonotic agents of E. coli $\mathrm{O} 157: \mathrm{H} 7$ in aceh cattle as well as from the farm workers and surrounding area are high. An appropriate control strategy is needed to apply in the aceh cattle farm to prevent from E. coli O157:H7 outbreak in the future.
\end{abstract}

Keywords: aceh cattle, pathogen, workers, water, E. coli, zoonoses.

\section{Introduction}

Escherichia coli $\mathrm{O} 157: \mathrm{H} 7$ (E. coli $\mathrm{O} 157: \mathrm{H} 7)$ is a very important food-borne pathogen to human, especially from animal products. In particular, cattle has been confirmed as the main reservoir for this strain of bacteria [1,2]. Possible route of occurrence of zoonotic transmission of E. coli 0157:H7 could be through consumption of undercooked meat or deficiently pasteurized dairy products or contact with contaminated fomites that contained Shiga-like toxin (stx), which is a virulence gene type in $E$. coli $\mathrm{O} 157: \mathrm{H} 7$ [3]. As a result, the case of infection could spread world-wide in human when lack of control program to the presence of $E$. coli O157:H7.
Several reports have also suggested some possible critical points of $E$. coli $\mathrm{O} 157: \mathrm{H} 7$ infection as well as the risk of spread to a wider population. Among of this point are hand of workers in farm and abattoir, water through, irrigation water, as well as fresh fruits and vegetables growing in surrounding area of cattle farm location $[2,4$, $5,6,7]$. It means, those critical points need to be closely monitored for any risk of the route of spread of $E$. coli O157:H7 infection both to animal and human.

In Indonesia, following the finding of E. coli O157:H7 in bali cattle, recently has been reported also for the present of this bacteria in aceh cattle, a local breed in Aceh Province $[8,9,10]$. It was confirmed by the finding of $s t x 2$ gene, which is one indication of the presence of $E$. coli O157:H7 [10]. However, very little information

* Corresponding author: teuku_rezaferasyi@unsyiah.ac.id 
available, if any, on the contamination of E. coli O157:H7 on the hand of workers and the water sources from surrounding sites in aceh cattle farm.

\section{Materials and Methods}

\subsection{Study Location}

This study was conducted in Livestock Breeding and Fodder Center (BPTU-HPT) of Directorate General of Livestock, Ministry of Agriculture of Republic of Indonesia, in Indrapuri of Aceh Besar District, Aceh Province, Indonesia. In this location, a number of 900 aceh cattle are raised in the area of $430 \mathrm{Ha}$. Most of cattle is raising under semi-intensive system, where the animals are allowed for free grazing during the day.

\subsection{Study Design}

A cross sectional was designed to examine the prevalence of $E$. coli $\mathrm{O} 157$ in this study. Sample were collected from faecal swab of cattle, swab of hand of farm workers and two water sources as well as water puddle obtained in surrounding cattle house area in the study location.

\subsubsection{Sample of Faecal Swab From Aceh Catlle}

A total of 85 faecal samples from rectal swabs of aceh cattle were collected [11]. Samples were obtained from randomly selected cattle, and then restrained for taking faecal swabs from their rectal.

\subsubsection{Sample of Farm-Workers Hand}

A total number of 15 workers from 11 cattle houses at study location were taken for samples of swab of their hand. All samples were collected from the palm of each hand of the workers before and after their work at the morning time (7.30 AM - 10.AM). Sterile swab sticks from the tubes were used for sample collection. The sampling procedures were conducted based on approach described by [12]. Sampling was performed by gentle rolling of swab stick horizontally, vertically, and diagonally in the palms of workers hand. The procedures were done aseptically to minimize the risk of contamination. Swabs were then placed back into the tubes and marked with sample code.

\subsubsection{Sample of Water Sources and Water Puddle}

The samples of water sources were collected from 11 cattle house locations in the study location. The water sources were divided into three different locations, namely the water containers, taps, and water puddle on the floor of several cattle houses. All samples were collected at the morning time (7.30 AM - 10.AM). Collection of samples was conducted using the prepared sterile swab sticks from the tubes. Sampling was performed by gentle rolling of swab stick horizontally, vertically, and diagonally in each water source. The samples were then placed back into the tubes and marked with sample code.

\subsection{Examination of Sample for Isolation of Bacteria}

The collected swab samples from faecal of cattle, hand of workers, and water sources were placed into a tube, and pooled in an ice - box containers and, then, immediately transported to the Laboratory of Microbiology of the Faculty of Veterinary Medicine of Syiah Kuala University for bacteriological culture.

The sample of swabs were then incubated at $37^{\circ} \mathrm{C}$ for $24 \mathrm{~h}$, after which the contents were diluted in sterile distilled water containing $0.85 \% \mathrm{NaCl}$. Then, the samples were isolated by culturing in an eosin methylene blue agar (EMBA) medium. The indicator of E. coli bacteria is the round-shape of colony with a colour of metallic green and black colour in the center [13]. The isolation was continued by performing Gram staining to confirm the $E$. coli bacteria. Then, the confirmation was followed by indol, methyl red, voges proskauer and citrate (IMVIC) test. For further test, the confirmed bacteria of E. coli were cultured in selective medium sorbitol Mac Conkey agar (SMAC) and incubated for 18h-24h. It was aimed to identify $E$. coli , which is indicated by clear appearance of colony and colourless or sorbitol negative [13].

\subsection{Molecular Analysis}

\subsubsection{DNA Extraction}

Total DNA was extracted separately using the gDNA PrestoTM Bacteria Mini kit (Geneaid) with slight modification. Purified total DNA $(50 \mu \mathrm{L}, \sim 200 \mu \mathrm{g} / \mathrm{mL})$ was eluted and used as the template for PCR assays as described in previous studies $[14,15]$.

\subsubsection{Polymerase Chain Reaction (PCR) Amplification for Gene 16S rRNA}

Gene 16SrRNA amplification was conducted using PCR tehnique. The amplification of this gene was using general primers of BacF and Unib. The BacF primer was used since it have complement with sustainable regions in bacterial domain. Then, UniB primer was used concerned to it universal sustainability for 16SrRNA gene to $E$. coli $[14,15]$. A further step for this amplification processes were also followed the method and technique in previous studies $[14,15]$. Determination of DNA sequence was conducted using a commercial service by Macrogen Inc., Korea. The determination processes were used a method of Dye Terminator (3'-dyelabelled dideoxynucleotide triphosphate).

\subsubsection{Multiplex-PCR Analysis}

Amplification using specific primers for E. coli $\mathrm{O} 157 \mathrm{H} 7$ (MyTaq Mix, Bioline) was performed using rfb, fliC, and st $x 2$ primers were used for multiplex-PCR analysis as shown in Table $1[11,16]$. In general, all of the multiplex primary sets are contained, each of $50 \mathrm{M}$ deoxynucleoside triphosphate, $2.0 \mathrm{mM} \mathrm{MgCl} 2$, each primer $0.2 \mathrm{M}, 1$ template $1 \mu \mathrm{L}$, and $1 \mathrm{U}$ from Taq DNA polymerase (MyTaq Mix, Bioline) The volume of this mix was 
adjusted to $25 \mu \mathrm{L}$. Denaturation step at $95^{\circ} \mathrm{C}$ for $5 \mathrm{~min}$, followed by 30 cycles of amplification with denaturation at $95^{\circ} \mathrm{C}$ for $30 \mathrm{~s}$, annealingat $58^{\circ} \mathrm{C}$ for $30 \mathrm{~s}$, and extension at $72^{\circ} \mathrm{C}$ for $30 \mathrm{~s}$, ending with a final extension at $72^{\circ} \mathrm{C}$ for $7 \mathrm{~min}$.

Table 1. The primers used for amplification of $r f b, f l i C$, and $s t x 2$ genes by PCR

\begin{tabular}{|c|c|c|c|}
\hline Gene & Target & Oligonucleotide sequence & $\begin{array}{l}\text { Amplic } \\
\text { on } \\
\text { product } \\
\text { (bp) }\end{array}$ \\
\hline $\begin{array}{l}r f b F \\
r f b R\end{array}$ & $\mathrm{O} 157$ & $\begin{array}{l}\text { 5'TCTCAGTGGGCGTTCTTATG-3' } \\
\text { 5'TACCCCCTCAACTGCTAATA-3' }\end{array}$ & 339 \\
\hline $\begin{array}{l}\text { fliCF } \\
\text { fliCR }\end{array}$ & $\mathrm{H} 7$ & $\begin{array}{l}\text { 5'CCCCCTGGACGAAGACTGAC-3', } \\
\text { 5' ACCGCTGGCAACAAAGGATA-3' }\end{array}$ & 401 \\
\hline $\begin{array}{l}\text { stx } 2 F \\
\text { stx } 2 R\end{array}$ & $\begin{array}{l}\text { Shiga } \\
\text { like } \\
\text { toxin2 }\end{array}$ & 5' TCCCGTCAACCTTCACTGTA-3' & 115 \\
\hline
\end{tabular}

\subsection{Data Anaysis}

The results of epidemiological data and molecular analysis obtained in this study were analysed descriptively.

\section{Results and Discussion}

\subsection{Isolation of $E$. coli}

The results of isolation showed that most samples obtained from cattle faecal swab, swab of hand of farm workers and water obtained in surrounding cattle house area in the study location were contaminated with $E$. coli bacteria. The results of test for 85 rectal faecal samples were indicated that all of them contained coliform bacteria. In particular, most of isolated bacteria was $E$. coli at the proportion of $85 \%$ (72 sample) of total sample and the rest of samples were contained the isolates of other coliforms. Similar results have also been obtained from the study in Nigeria and Bangladesh, both reported the prevalence of $E$. coli from sample of rectal swab of cattle between $75 \%-80 \%[17,18]$. Interestingly, both of studies were taken sample from the cattle those assumed healthy. It is similar to the assumption we have made when starting our study, since we collected sample from cattle raised in livestock breeding centre.

Then, from some of the results of swab of farm workers hand, both before and after work in the same day, also indicated E. coli contamination. As shown in Table 2 that $20 \%$ of 15 workers hand were contaminated by the bacteria before work. On the other hand, it was only 6,6\% of workers hand contaminated by E. coli after work. This results is in contrast to the high number of isolate obtained from rectal swab of aceh cattle above. Furthermore, the lower number of $E$. coli isolated from the swab sample of workers hand after work as compared to samples before work is another surprising result in this study. Actualy, it is hypothesized that the presence of the pathogens on farm workers' hands could occurred as a result of contact with cattle faecal matter [4]. Therefore, a further study is needed to explain the current findings.

Table 2. Results of isolation of E. coli from swab of hand of farm workers, both before and after work in the same day at cattle houses in Livestock Breeding and Fodder Center, Aceh Besar District. Odds ratio (OR) was estimated to measures of association between contamination of the bacteria and the time of work.

\begin{tabular}{cccc}
\hline \multirow{2}{*}{$\begin{array}{c}\text { Swab of hand of } \\
\text { farm workers }\end{array}$} & \multicolumn{2}{c}{$\begin{array}{c}\text { Results of E. coli } \\
\text { Isolation }\end{array}$} & \\
\cline { 2 - 3 } Total sample \\
\cline { 2 - 3 } & Positive & Negative & \\
\hline After work & 1 & 14 & 15 \\
\hline Before work & 3 & 12 & 15 \\
\hline Total sample & 4 & 26 & 30 \\
\hline
\end{tabular}

Next, E. coli contamination was also obtained from water obtained in surrounding cattle house area. It can be seen from Table 3 that a high percentage (63.64\%) of $E$. coli was isolated from tap water in the cattle houses. Then, E. coli was also isolated from $45.45 \%$ of sample obtained from water puddle on the floor of 11 cattle houses location. A lowest percentage of isolation of the bacteria was only obtained in the water containers, which is only $9.1 \%$ of all location for sample collection.

Table 3. Results of isolation of E. coli based on samples collected from water containers, taps, and water puddle on the floor of 11 cattle houses location in Livestock Breeding and Fodder Center, Aceh Besar District.

\begin{tabular}{cccc}
\hline \multirow{2}{*}{$\begin{array}{c}\text { Source of Water } \\
\text { Sample }\end{array}$} & \multicolumn{2}{c}{$\begin{array}{c}\text { Results of E. coli } \\
\text { Isolation }\end{array}$} & $\begin{array}{c}\text { Total } \\
\text { Sample }\end{array}$ \\
\cline { 2 - 3 } & Positive & Negative & 11 \\
\hline Tap & 7 & 4 & 11 \\
\hline $\begin{array}{c}\text { Water puddle on } \\
\text { the floor }\end{array}$ & 5 & 6 & 11 \\
\hline Water container & 1 & 10 & 33 \\
\hline Total Sample & 13 & 20 & \\
\hline
\end{tabular}

A high percentage of isolation of $E$. coli from tap water sample could be caused by a large pool of standing water before drink by the cattle [7]. In addition, the source of water need to be check further, which may be contaminated by a material that contained E. coli bacteria, i.e. animal feces or human stool $[5,6]$. A lower percentage of positive results obtained from Water puddle on the floor might be as a result of cleaning management of cattle houses floor two times per day both using water and disinfectant. Then, a lowest percentage of $E$. coli isolated from water container could occurred because it is an open container that everyday received direct sunlight exposure [19].

\subsection{Molecular subtyping of $E$. coli $\mathrm{O} 157: \mathrm{H} 7$ genes}

The isolates of $E$. coli obtained from 72 samples of faecal swab of aceh cattle were further analyzed with multiplexPCR analysis. It was obtained that three of 72 samples showed the presence of gene $f l i C$ (401 bp), and $r f b$ (339 
bp). However, only two samples of three that have genes for $E$. coli $\mathrm{O} 157: \mathrm{H} 7$, which was indicated by the presence of stx 2 gene (115 bp) (Figure 1).

The results of our study revealed that the isolate $E$. coli of TR-9 and TR-10 was detected for the presence of Shiga-like toxin 2 (stx2) gene, which is a virulence gene type in E. coli O157:H7. The presence of this gene is an indication of high pathogenicity of infection of $E$. coli O157:H7 [3]. Although, the prevalence of E. coli $\mathrm{O} 157: \mathrm{H} 7$ in this study is categorized low (2.8\%), it is need to be anticipated for the spread of this pathogen agent to other potential point of risk of the spread of the bacteria in cattle farm location. In particular, to prevent human infection, especially to farm workers and veterinarian as part of high risk group, since E. coli $\mathrm{O} 157: \mathrm{H} 7$ is known as zoonotic agent [20].

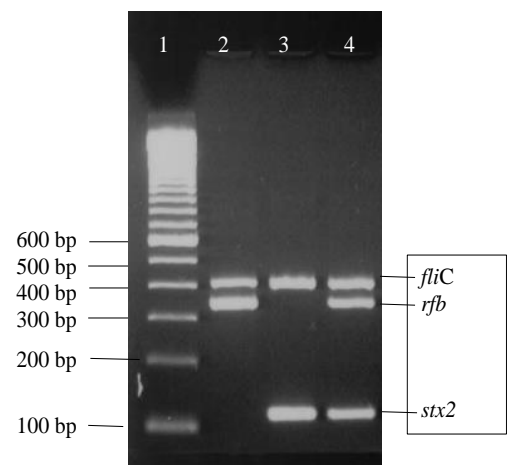

Figure 1. Determination of the presense of E. coli $\quad$ O157:H7 genes in sample obtained from faecal swab of aceh cattle by using the multiplex PCR technique with primers fliC (401 bp), rfb (339 bp), and stx2 (115 bp). 1: marker DNA $100 \mathrm{bp} ; 2$. Sample isolate TR-8 (Negative sample); 3. TR-9 (Positive sample); 4. TR-10 (Positive sample).

\section{Conclusion}

The most potential water sources for E. coli contamination were the water in taps, and water puddle on the floor of cattle houses. Then, two of samples of E. coli isolated from rectal swab were confirmed as E. coli O157:H7 using PCR test, based on the presence of stx2 gene. The risk of presence of $E$. coli as zoonotic agents of E. coli $\mathrm{O} 157: \mathrm{H} 7$ in aceh cattle as well as from the farm workers and surrounding area are high. An appropriate control strategy is needed to apply in the aceh cattle farm to prevent from E. coli $\mathrm{O} 157: \mathrm{H} 7$ outbreak in the future.

\section{Acknowledgments}

The authors would like to grateful Universitas Syiah Kuala for supporting this study through Research Grant Scheme of Penelitian Unggulan Unsyiah of 2018. Then, we would like also to thanks BPTU-HPT, Indrapuri, Aceh Besar for provided us with supporting facilities to conduct field works.

\section{References}

1. Brusa V, Aliverti V, Aliverti $\mathrm{F}$, et al.: Shiga toxin producing Escherichia coli in beef retail markets from Argentina. Front Cell Infect Microbiol. 2013; 2 (171): 1-6.

2. Gossman W, Wasey A, Salen P: Escherichia Coli (E Coli 0157 H7). Treasure Island (FL): StatPearls Publishing. 2019.

3. Fraser ME, Fujinaga M, Cherney MM, et al.: Structure of Shiga Toxin Type 2 (Stx2) from Escherichia coli O157:H7. J.Biological Chemistry. 2004; 279: 27511-27517.

4. Shamsul BMT, Adamu MT, Mohd DMN, et al.: Prevalence of Escherichia Coli 0157:H7 and Enterobacteriaceae on hands of workers in halal cattle abattoirs in peninsular Malaysia. Malays J Med Sci. 2016; 23(5):65-71.

5. Luby SP, Amal KH, Tarique MH, et al.: Microbiological Contamination of Drinking Water Associated with Subsequent Child Diarrhea. Am J Trop Med Hyg. 2015; 93(5): 904-911.

6. Ercumen A, Pickering AJ, Kwong LH, et al: Animal Feces Contribute to Domestic Fecal Contamination: Evidence from E. coli Measured in Water, Hands, Food, Flies, and Soil in Bangladesh. Environ Sci Technol. 2017; 51(15):8725-8734.

7. Beauvais W, Gart EV, Bean M, et al:: The prevalence of Escherichia coli 0157:H7 fecal shedding in feedlot pens is affected by the waterto-cattle ratio: $A$ randomized controlled trial. PLOS ONE. 2018; 13(2): e0192149.

8. Abdullah, MAN, Noor RR, Martojo H, et al:: Keragaman Fenotipik Sapi Aceh Di Nanggroe Aceh Darussalam. $J$. Indon. Trop. Anim. Agric. 2006; 32(1): 11-21.

9. Suardana IW, PJRA Putri, Besung INK: Isolasi dan Identifikasi Escherichia coli O157:H7 pada Feses Sapi di Kecamatan Petang, Kabupaten Badung-Bali. Buletin Veteriner Udayana. 2016; 8(1): 30-35.

10. Abrar M, Ferasyi TR, Amiruddin, et al.: Molecular subtyping and dna sequencing homology of Escherichia coli O157:H7 isolated from Aceh cattle. Research development and application in biotechnology for natural resources sustainability, Proceeding of The 4th International Conference on Biological Sciences and Biotechnology. North Sumatera Universty, Medan, Indonesia. 2018. IOP Conf. Ser.: Earth Environ. Sci. 305 012025 .

11. Suardana, IW, Artama WT, Asmara W, et al.: Identification of Escherichia Coli 0157:H7 and detection of shiga like toxin 1 and 2 genes from animal feces beef, and human feces. Jurnal Veteriner. 2010; 11(4): 264-270.

12. Dahiru JY, Abubakar FA, Idris $\mathrm{H}$, et al.: Bacterial contamination of food handlers at various restaurants in Kano State Metropolis, Kano Nigeria. Int. J. Curr. Microbiol. App. Sci. 2016; 5(5): 165-170.

13. Bridson EY. The Oxoid Manual 9th Edition. Oxoid Limited, England. 2006.

14. Balqis U, Hambal M, Admi M, et al:: Escherichia fergusonii identified in preputial swabs from healthy Aceh cattle by phylogenetic 16S rRNA analysis. Malaysian Journal of Microbiology. 2018; 14(3): 229-235. 
15. Sari WN, Safika, Darmawi, et al: Isolation and identification of a cellulolytic Enterobacter from rumen of Aceh cattle. Veterinary World. 2017; 10(12): 1515-1520.

16. Hu Y, Zhang Q, Meitzler JC. Rapid and sensitive detection of Escherichia coli 0157:H7 in bovine faeces by a multiplex PCR. Journal of Applied Microbiology. 1999; 87(6): 867-876.

17. Ogunleye AO, Okunlade AO, Jeminlehin FO et al.: Antibiotic resistance in Escherichia coli isolated from healthy cattle at a major cattle market in Ibadan, Oyo State, South Western, Nigeria. Afr J Microbiol Res. 2013; 7: 4572-4575.
18. Hassan J, Parvej MS, Rahman MB, et al.: Prevalence and Characterization of Escherichia coli from Rectal Swab of Apparently Healthy Cattle in Mymensingh, Bangladesh. Microbes and Health. 2014; 3(1): 12-14.

19. LeJeune JT, Besser TE,. Merrill NL, et al.: Livestock Drinking Water Microbiology and the Factors Influencing the Quality of Drinking Water Offered to Cattle. J. Dairy Sci. 2001; 84(8):1856-1862.

20. Wasteson Y: Zoonotic Escherichia coli. Acta Vet Scand 2001; 43(1): 79-84. 